\title{
Impact of Fraxinus excelsior dieback on biota of ash-associated lichen epiphytes at the landscape and community level
}

\section{Anna Łubek ${ }^{1}$ - Martin Kukwa² $\cdot$ Patryk Czortek ${ }^{3} \cdot$ Bogdan Jaroszewicz $^{3}$}

Received: 9 June 2019 / Revised: 18 October 2019 / Accepted: 23 October 2019 /

Published online: 31 October 2019

(C) The Author(s) 2019

\begin{abstract}
The landscape-scale extinction of a tree species may have a negative impact on diversity of associated epiphytic species. We used ordination and hierarchical clustering methods to assess landscape and the community level effects of reduction in the abundance of European ash Fraxinus excelsior, caused by ash dieback, on the associated epiphytic lichen biota in Białowieża Forest (Poland) - the best preserved forest complex in Central Europe. At the landscape level ash decline impact on the biota of ash-associated epiphytic lichens was weak, due to the high diversity of tree species, which may serve as potential alternative hosts. At this level, oak and hornbeam are the most important alternative hosts, assuring the maintenance of ash-associated epiphytic lichens. Lime, alder, and hazel appeared to be less important but still may serve as substitute phorophytes to approximately $2 / 3$ of the ash-associated lichen biota. About $90 \%$ of epiphytic biota are likely to survive on the landscape scale. However, at the community level of alder-ash floodplain forest, where ash was dominant, about $50 \%$ of ash-associated epiphytic lichen species are threatened by ash dieback. Our results highlight the importance of a spatial scale in conservation biology. Protection of large forest areas with rich diversity of phorophyte trees increases chances of survival of the associated epiphytic organisms.
\end{abstract}

Keywords European ash · Foundation species $\cdot$ Hot spot tree $\cdot$ Metapopulation . Phorophytes · Primeval forest

Communicated by David Hawksworth.

This article belongs to the Topical Collection: Forest and plantation biodiversity.

Electronic supplementary material The online version of this article (https://doi.org/10.1007/s1053 1-019-01890-w) contains supplementary material, which is available to authorized users.

Anna Łubek

anna.lubek@ujk.edu.pl

Extended author information available on the last page of the article 


\section{Introduction}

The dieback of European ash Fraxinus excelsior has been reported since the early 1990s. It started in north-eastern Poland and during the next years expanded to neighboring countries (Przybył 2002; Bakys et al. 2009a; Pautasso et al. 2013; Gross et al. 2014a). Recently, a severe dieback of ash, which includes trees in all age stages (Gross et al. 2014a; Needham et al. 2016; Enderle et al. 2018), can be observed in most European countries (Bakys et al. 2009a, b; Kowalski and Holdenrieder 2009a, b; Allen et al. 2010; Beck et al. 2016; Coker et al. 2019). It is caused mainly by the fungus Hymenoscyphus fraxineus, which induces wilting and loss of leaves, thinning of crowns, darkening of wood, necrosis and neoplastic changes on trunks and branches, and finally leads to the deaths of trees (Baral et al. 2014; Gross et al. 2014b), but other pathogens that weaken this tree are also reported, e.g. fungus Rigidoporus ulmarius (Lücking et al. 2019). Regardless the region, the massive extinction of ash has contributed to the loss of even more than $90 \%$ of the trees in the entire range of F. excelsior (Skovsgaard et al. 2010; Jönsson and Thor 2012; Cholewińska et al. 2018; Matisone et al. 2018). The susceptibility of ash to this disease is rising with the increasing intensity of soil water relations disturbances, linked with the water shortage caused by climate change, i.e. the increase in temperature and decrease in precipitation (Allen et al. 2010; Baral et al. 2014; Gross et al. 2014b). Therefore, due to the progressive climate change, ash recovery will be difficult and even impossible in some cases (Enderle et al. 2018). Despite the fact that some populations of ash may be resistant to infections by $H$. fraxineus (Enderle et al. 2015; Pušpure et al. 2017), which creates an opportunity for ash recovery, the observed regeneration of ash has not brought the expected results (Enderle et al. 2018).

The natural geographical range of European ash covers temperate lowland Europe from the Atlantic coast to the Volga River, except for most of the Mediterranean and northern Fennoscandia (Beck et al. 2016). It occurs in numerous types of forest communities as an admixture, or it can be the dominant tree species in floodplain and ravine forests, or forests growing on dry calcareous soils (Beck et al. 2016). The extinction of ash, especially in the phytocoenoses where it dominates, may result in transforming the functioning of entire forest ecosystems. It may lead, e.g. to increasing the availability of light due to gaps developing in the forest canopy and an increase in the amount of some substrates, especially deadwood. High deadwood availability drives changes in the composition of species in the forest understory, i.e. by creating a suitable microclimate and habitat conditions for the development of numerous groups of organisms, as well as increased nutrient availability in the soil (Eschtruth et al. 2006; Kurz et al. 2008; Ford et al. 2012; Mitchell et al. 2014a, b, 2016). However, the most important question connected with the ash dieback is how it will affect organisms closely associated with this tree, such as invertebrates, bryophytes, fungi, and lichen epiphytes (Jönsson and Thor 2012; Mitchell et al. 2014a, b, 2016), as F. excelsior is a foundation species for them. Growing in floodplain and ravine forests in high abundance, ash shapes the functioning and dynamics of these ecosystems and is considered to be a hotspot of biodiversity (Ellison et al. 2005). It is also a source of microhabitats (Barkman 1958) for many specialized groups of organisms, especially epiphytes (e.g. Lõhmus and Runnel 2014; Mitchell et al. 2014a; Preikša et al. 2015). Ash in primeval forests reaches its maximum age and size, and provides decaying wood after its death, which shapes unique habitats important for species conservation and preservation of the full biodiversity of organisms associated with them (Mitchell et al. 2014b; Preikša et al. 2015). 
Epiphytic lichens are extremely vulnerable to any change in an environment. Apart from climate change and eutrophication, which are pointed out as main drivers of the changes in species composition of epiphytes (van Herk 2009), other important factors potentially causing these changes are those linked with shifts in the composition of tree phorophytes in forest communities (Pipp et al. 2001). However, the consequences of the ash dieback on the diversity of epiphytic lichen biota still have not been well documented. Jönsson and Thor (2012) reported that ash dieback could cause a 38\% reduction in the number of ash-associated lichen epiphytes in forests in Sweden. Similar projected losses of species diversity of epiphytic lichens occurring on ash have been reported from Great Britain (Mitchell et al. 2014a, 2016). However, epiphytic lichens are not restricted to only one species of tree, but to the group of tree species with a similar complex of physical and chemical properties of their bark (Barkman 1958). Therefore lichens associated with ash may find a suitable substrate on other species of trees, such as oak, hazel, and sycamore maple, which was reported for all kinds of forests in Great Britain by Mitchell et al. (2014a, 2016). However, similar studies have not been conducted so far in old natural forests excluded from forest management and with very modest direct human influence. The only example of these ecosystems in temperate lowland Europe is Białowieża Primeval Forest, which plays an important role in the conservation and maintenance of diversity of lichen epiphytes, especially those occurring with high abundances on ash (Cieśliński et al. 1995). Therefore, taking into account the close to $98 \%$ loss of ash trees in Białowieża Forest stands (Cholewinska et al. 2018), there is an urgent need to determine the impact of the ash dieback on the preservation of the epiphytic lichen biota associated with this tree, with particular emphasis on forest communities where ash predominates.

The main aim of our work was to estimate whether the ash dieback is driving the loss of lichen epiphytes diversity amongst forest communities not affected by humans, on the same scale as was reported in Northern and Western Europe, and what other phorophyte tree species can be considered as important alternative hosts for lichens associated with ash. We hypothesized that the ash dieback effect on ash-associated lichen biota diversity would depend on the spatial scale considered: (i) moderate at the landscape scale (of the entire forest ecosystem), due to the high diversity of alternative host species, and (ii) severe at the community scale (of the ash-dominated floodplain forest) due to the absence of alternative tree hosts in the closest neighborhood.

\section{Materials and methods}

\section{Study area}

The Białowieża Forest, situated in the north-eastern part of Poland, is the best preserved forest area on the European lowland (Sabatini et al. 2018). It is characterized by a high richness of species of plants, animals, and fungi; high structural forest complexity; and long-lasting continuity of biological processes and tree cover (Latałowa et al. 2016). In the heart of the Białowieża Forest the Białowieża National Park is situated (Fig. 1), which protects its oldest and best preserved parts, excluded from direct human interference since the beginning of the 1920s. In comparison to forests outside of the national park, it is characterized by substantially higher species richness, a higher age of trees, and stands with more complex spatial structure (Keczyński 2017). Uncontrolled disturbances, e.g. forest diebacks, insect outbreaks and windthrows resulting in uprooted trees and high amounts 


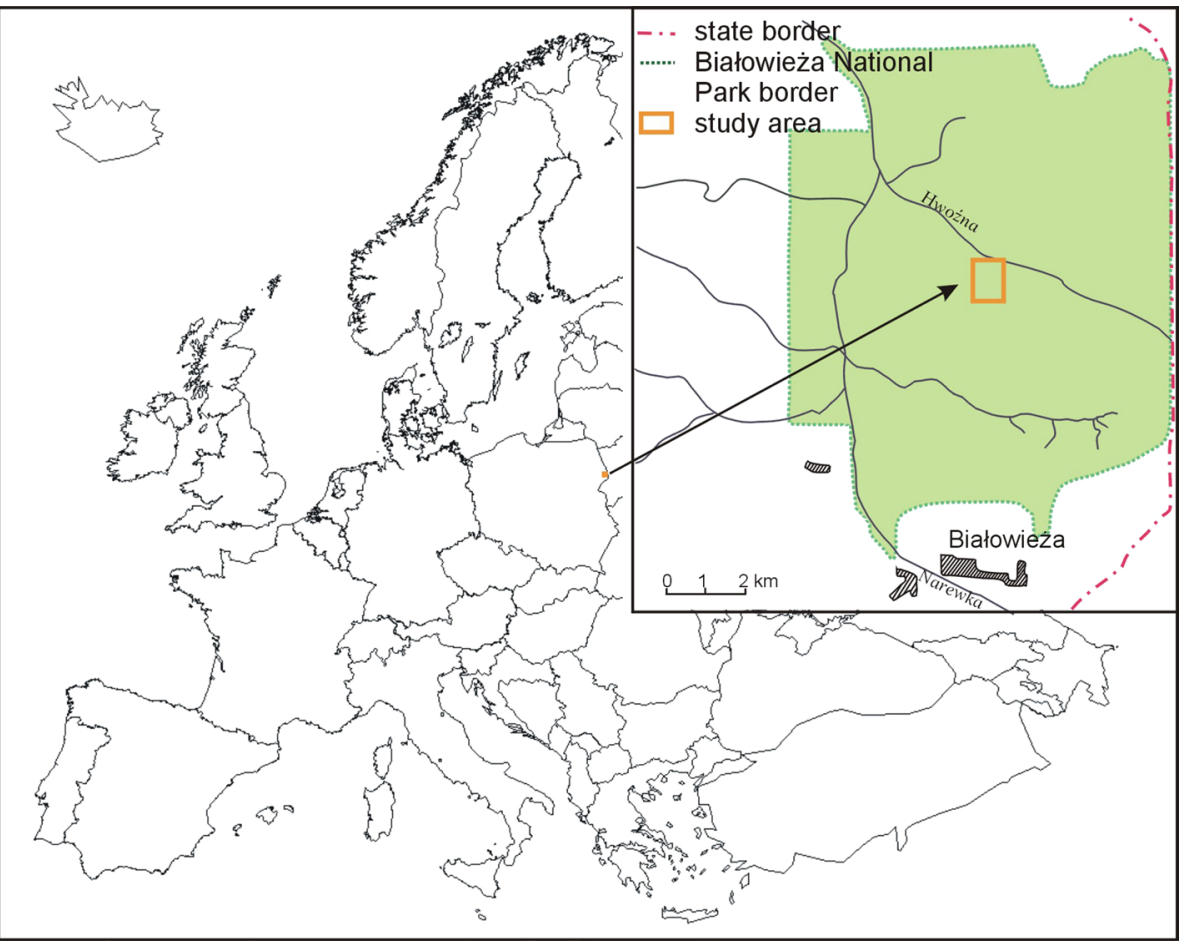

Fig. 1 The study area in Białowieża National Park, NE Poland

of deadwood in various stages of decomposition, determine the great complexity of microhabitats. This high degree of naturalness and the specific microclimate of the Białowieża National Park is well reflected in the great diversity of species of lichen biota (Cieśliński et al. 1995).

The forests of Białowieża National Park are affected by air pollutions, including sulfur and nitrogen dioxides. Sulfur average annual deposition decreased considerably during the last two decades: in 2000 it was about $2.5 \mu \mathrm{g} / \mathrm{m}^{3}$, in 2003 about $2 \mu \mathrm{g} / \mathrm{m}^{3}$, in 2013 below $2 \mu \mathrm{g} / \mathrm{m}^{3}$, and in 2015 below $1.2 \mu \mathrm{g} / \mathrm{m}^{3}$ (Monitoring Lasów w Polsce. Raport 2000, 2003, 2013 , 2015). The opposite trend was observed in concentrations of another pollutant$\mathrm{NO}_{2}$ : it slightly decreased at the beginning of the century from $4.2 \mu \mathrm{g} / \mathrm{m}^{3}$ (in 2000), to $3.9 \mu \mathrm{g} / \mathrm{m}^{3}$ and $3.6 \mu \mathrm{g} / \mathrm{m}^{3}$ (in 2003 and 2013 , respectively) but increased back to $4.2 \mu \mathrm{g} / \mathrm{m}^{3}$ in 2015. Nitrogen deposition is probably one of the most important factors causing habitat eutrophication, with stable dry deposition at the level of 2-3 kg/ha/year in 1986-2007, but increasing wet deposition (from 7 to $9 \mathrm{~kg} / \mathrm{ha} /$ year in 1986-1995 to $14 \mathrm{~kg} / \mathrm{ha} /$ year in 2005) (Malzahn 2004; Malzahn et al. 2009; see also Łubek et al. 2018).

\section{Study design}

Our research was conducted in 2014-2015 on 144 permanent plots $(100 \times 100 \mathrm{~m}$ each) located in the core area of the Białowieża National Park (Faliński and Mułenko 1997). There are six forest communities occurring in the investigated area: mixed 
deciduous fertile oak-lime-hornbeam forest Tilio-Carpinetum (54 plots), floodplain streamside alder-ash forest Circaeo-Alnetum (22 plots), swamp alder carr forest Carici elongatae-Alnetum (18 plots), coniferous pine-oak mixed forest Pino-Quercetum (18 plots), coniferous moist oak-spruce forest Querco-Piceetum (5 plots) and coniferous mesic (spruce)-pine forest Peucedano-Pinetum (27 plots). All these communities differ by species composition and dominance of trees and shrubs (comp. Supplementary Table 1). In our analysis all coniferous communities (pine-oak mixed forest, moist oakspruce forest and mesic (spruce)-pine forest) were combined into one group due to their similarity of tree species composition and a great share of conifer trees.

In the studied communities, ash may play the role of a dominant or an admixture tree, or it does not occur in some of them at all. Therefore, we considered the occurrence of ash at two spatial scales: (i) the landscape scale-including all six forest communities, and (ii) the community scale-including only the floodplain streamside alder-ash forest Circaeo-Alnetum. At the landscape scale, composed of 144 plots, ash was present on 61 plots and did not occur on 83 plots. At the community scale, which covered 22 plots, ash was the main component of stands, co-dominating with alder.

The team of two researchers worked on each plot for 3-4 h, investigating all possible microhabitats (for details see Łubek et al. 2018). A magnifying hand lens with light was used for lichen determination and samples of specimens difficult to identify in the field were collected for laboratory confirmation. On each research plot all species of epiphytic lichens on all available tree phorophytes and in each type of forest community were recorded (Supplementary Table 1). The abundance of each lichen species on all phorophytes (or microhabitats) was estimated at the plot level using four-step scale, where zero stands for lack of species and three for the highest abundance. In addition, independently from plots, we recorded also the occurrences of each lichen species on each individual tree phorophyte per plot.

In the studied area we examined alive ash trees (young and old), as well as dead ones (standing and lying). Despite the fact that the many ashes were dead, in the suitable light conditions and until the bark of the tree was intact, epiphytic lichens were still able to grow. To make sure that we dealt with the lichen diversity comparable to the "baseline" of the ash lichen biota, we checked the data obtained in the 1980s (Cieśliński et al. 1995; Cieśliński and Czyżewska 1997), when the ash population was not affected by ash dieback yet. All species recorded on bark of ash in the past have also been confirmed today, except Lobarina scrobiculata (occurred in the past only on one site), Bryoria implexa and Evernia divaricata (rare species recorded recently only on twigs of spruce), Buellia erubescens (rare species found recently only once on hornbeam), Phlyctis agelaea and Pyrenula laevigata (rare species recorded recently only on bark of lime and hornbeam), Imshaugia aleurites and Parmeliopsis ambigua (frequent species recorded recently on bark of birch, alder, spruce and pine); Biatora beckhausii and Ochrolechia subviridis were incorrectly reported what was confirmed by the revision of herbarium material. These lichens were not included into analysis, because they were not confirmed on ash during the resurvey.

The nomenclature of lichen species followed Fałtynowicz and Kossowska (2016), and for those not included in the previous work, Sérusiaux et al. (2010), Czarnota and Guzow-Krzemińska (2018), Ertz et al. (2018), Boluda et al. (2019). The collected material was deposited in the lichen herbarium of the Jan Kochanowski University in Kielce (KTC) and the University of Gdańsk (UGDA). 


\section{Data analyses}

We included within the analyses 172 species of lichen epiphytes recorded on ash in our study, including 15 epiphytes occurring on ash exclusively (Supplementary Table 1). At the landscape scale analyses we used all records of ash-associated species of lichens on all tree species in all 144 study plots. At the community scale, analyses were limited to species of lichens recorded on the 22 plots covered by the ash-alder floodplain forest community. For the community scale we considered lichens occurring on ashes and alders, as this trees build the floodplain forest community. We used information on the ecological requirements of lichen species (Wirth Ecological Indicator Values (WEIV; see Supplementary Table 1) with respect to: light (WEIV-L), temperature (WEIV-T), moisture (WEIV-F), and reaction (acidity; WEIV-R), provided by Wirth (2010). These indicators use a nine-step scale, with 1 being the lowest and 9 the highest degree of the respective environmental factor. For WEIV R, number 1 means the highest acidity and 9 the lowest. This information allowed us to illustrate the ecological requirements of the studied biota of epiphytic lichens.

To explore the compositional patterns of ash-associated epiphytic lichens amongst (i) all analyzed plots, (ii) plots containing ash (as an admixture or a main tree in forests on analyzed plots), (iii) plots not containing ash, and between (iv) phorophyte species (independently of the forest community), we applied Non-Metric Multidimensional Scaling with pairwise Bray-Curtis dissimilarity matrices (NMDS; vegan::rda() function; Oksanen et al. 2018). Thus, for each of the four approaches mentioned above, one separate NMDS ordination was performed. The vegan::envfit() function was employed to explore relationships between the distribution of points representing plots in NMDS ordination performed separately for plots containing and not containing ash and tree phorophytes in ordination space and: (i) mean values of WEIVs, (ii) species richness, (iii) Shannon diversity index and (iv) Pielou evenness index. This was done by fitting of the above-mentioned variables as passive vectors into the ordination space. For each vector the determination coefficient $R^{2}$ and $P$-values were calculated using a permutation test with 999 iterations.

The Bray-Curtis compositional dissimilarity matrix was calculated at the landscape scale for each plot versus each plot within two-group of plots, those containing ash and not containing ash, using the vegan::vegdist() function, to detect compositional dissimilarities between the the two groups of plots. The same method was used to calculate dissimilarities in species composition of lichen biota among tree phorophytes at the landscape scale. Thus, to reveal interspecific compositional dissimilarities between tree hosts, for each phorophyte versus each phorophyte the Bray-Curtis compositional index was calculated. To visualize the compositional similarities of epiphytic lichen assemblages among phorophytes, as well as to explore which phorophytes were most similar to ash in respect of epiphytes composition, a hierarchal clustering (based on the Bray-Curtis dissimilarity index $(\bar{x})$ ), using a generalization of the weighted average linkage (beta-flexible method, which is a constant version of the Lance-Williams formula), was performed (using cluster::agnes () function; Maechler 2019).

We used the non-parametric Mann-Whitney $U$ test to find whether there were compositional differences between the lichen biota of plots containing and not containing ash, focusing on: (i) Bray-Curtis dissimilarity index $(\bar{x})$, (ii) the proportion of epiphytic lichens representing different ecological requirements for WEIV-L, WEIV-T, WEIV$\mathrm{F}$, and WEIV-R, (iii) species richness (iv) diversity (Shannon index) and (v) evenness 
(Pielou index). The level of significance of differences was set at $\alpha=0.05$. In addition, to focus on the ecological significance of the results, more detailed-regardless of $P$ values - size effects were included (Nakagawa and Cuthill 2007; Steel et al. 2013).

To check whether there were significant differences in species frequency (i.e. the number of species occurrences on a specific phorophyte) between epiphytes occurring on alder and ash phorophytes at the community scale, the Chi square test $\left(X^{2}\right)$ was used (with the maximum level of significance set at $\alpha<0.05$ ). We limited this test only to species that appeared at least five times, either on alder or ash, which reduced the number of species from 172, recorded at the landscape scale, to 71. All analyses were performed in R software (R Core Team 2019).

\section{Results}

On the landscape scale, NMDS ordination, performed for all plots containing and not containing ash, revealed a compositional continuum (high compositional similarities) of lichen biota regardless of forest community. Only plots not containing ash and representing coniferous forest showed relatively large compositional dissimilarities with other forest communities, i.e. both containing and not-containing ash (Fig. 2a). Considering results of NMDS performed only for plots containing ash, compositional dissimilarities between plots representing different forest communities were relatively low (Fig. 2b). Species composition of most plots representing a mixed deciduous fertile oak-lime-hornbeam forest was characterized by a high proportion of lichen species with higher values of the WEIV-T, WEIV-R, and Pielou evenness index (right side of NMDS plot; Fig. 2b; Table 1). Species composition of most of floodplain and swamp forest plots (left side of NMDS plot on Fig. 2b) was described by high values of WEIV-L, whereas the highest values of species richness and Shannon-Wiener index were related with some plots representing floodplain forest. Distribution of plots not containing ash revealed partial compositional discontinuum of the lichen biota across forest vegetation types, pointing out large compositional dissimilarities between most of plots representing mixed deciduous and coniferous forest (Fig. 2c). Only a few plots, representing swamp, mixed deciduous, and coniferous forest were overlapping in the middle part of the NMDS plot. Species composition of most mixed deciduous forest plots was described by high values of WEIV-T, WEIV-F, WEIV-R, and by high Pielou evenness index. Considering vectors representing species richness and Shannon-Wiener index, relationships with the same plots were less pronounced (Fig. 2c; Table 1). In contrast, species composition of coniferous forests was characterized by low values of all the above-mentioned vectors and high values of WEIV-L.

The mean Bray-Curtis compositional dissimilarity index of lichen biota was significantly higher for plots with the presence of ash than for those without this tree species (Fig. 3). Plots containing ash were characterized also by significantly higher species richness of lichens and a higher proportion of lichen species with higher light requirements (Fig. 3). On the plots without ash trees, Pielou evenness and Shannon diversity of the lichen biota were higher and the proportion of lichen species with higher temperature, higher moisture demands, and lower acidity requirements were higher than on the plots containing ash (Fig. 3).

At the tree phorophyte level we revealed that communities of lichen epiphytes growing on the bark of oak, lime, ash, and hornbeam were characterized by high values of WEIV-F, species richness, and Shannon diversity (Fig. 4a; Table 1). Considering results 
(a)

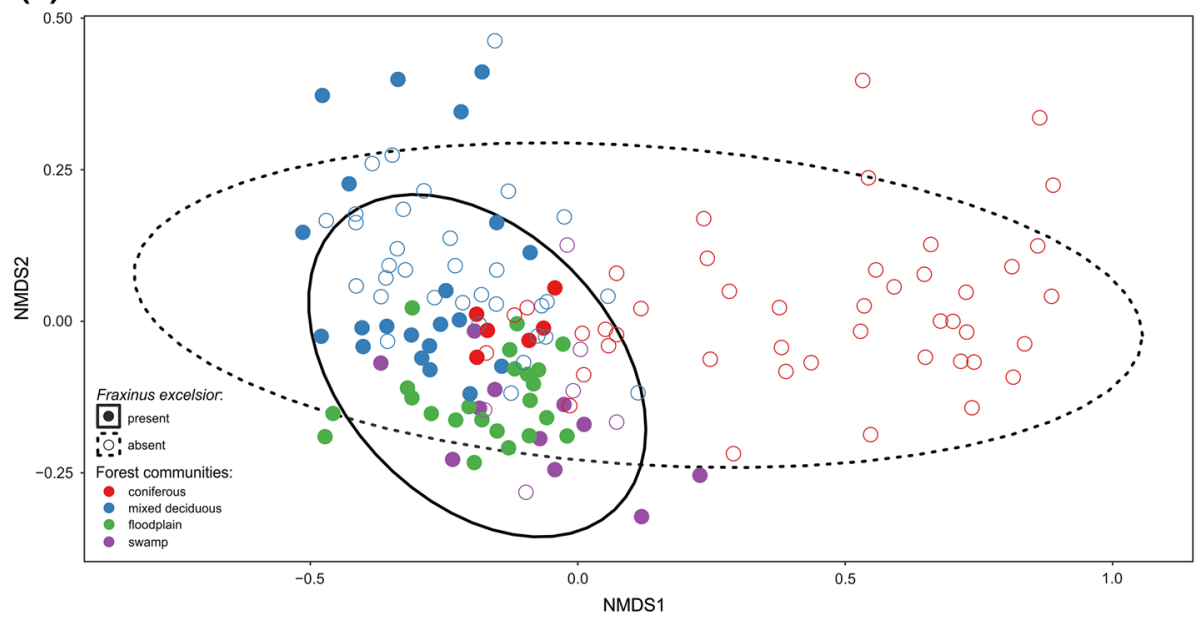

(b)

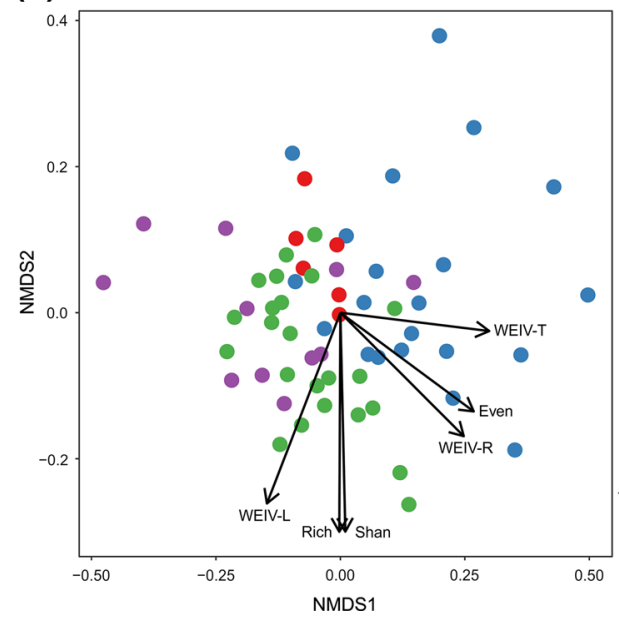

(c)

Fig. 2 Results of NMDS ordination performed for the species composition of epiphytic lichens at the landscape level for (a) all plots containing and not containing Fraxinus excelsior (as an admixture or a main tree in forests); solid and dashed lines represent ellipses with a 95\% confidence level (b) plots containing $F$. excelsior and (c) not containing F. excelsior. Points in (a), (b) and (c) represent plots. Arrows in (b) and (c) represent vectors significantly $(P<0.05)$ correlated with the results of the analyses: Rich-species richness, Shan-Shannon diversity index, Even-Pielou evenness index, WEIV-L-light Wirth's Ecological Indicator Value (WEIV), WEIV-T-temperature WEIV, WEIV-F-moisture WEIV, WEIV-R—reaction WEIV

of hierarchical clustering, species composition of epiphytic lichens growing on ash was the most similar to those occurring on: alder, hazel, hornbeam, lime and oak (Fig. 4b), with $\bar{x}$ ranging from 0.49 for ash and oak, and 0.61 for ash and hornbeam (Fig. 4c). We revealed the lowest compositional dissimilarities between lichen communities growing on alder and lime $(\bar{x}=0.31)$, as well as alder and oak $(\bar{x}=0.42)$. At the same time lime showed low dissimilarities of lichen epiphytes assemblages with: hazel $(\bar{x}=0.41)$, birch and ash (for both tress $\bar{x}=0.50)$, as well as hornbeam $(\bar{x}=0.51$; Fig. $4 \mathrm{c})$. Of the 172 epiphytes growing on 
Table 1 Parameters of environmental variables passively fitted to results of the NMDS ordinations (Figs. 2a, b, 4a)

\begin{tabular}{|c|c|c|c|c|c|}
\hline Parameter & Abbreviation & NMDS1 & NMDS2 & $R^{2}$ & $P$ \\
\hline \multicolumn{6}{|c|}{ Plots containing Fraxinus excelsior: } \\
\hline Species richness & Rich & -0.0072 & -0.9999 & 0.2388 & 0.001 \\
\hline Shannon diversity index & Shan & 0.0331 & -0.9998 & 0.2728 & 0.001 \\
\hline Pielou evenness index & Even & 0.8926 & -0.4506 & 0.3771 & 0.001 \\
\hline Light WEIV & WEIV-L & -0.4917 & -0.8707 & 0.4590 & 0.001 \\
\hline Temperature WEIV & WEIV-T & 0.9964 & -0.0838 & 0.7623 & 0.001 \\
\hline Moisture WEIV & WEIV-F & -0.8990 & -0.4378 & 0.0679 & 0.126 \\
\hline Reaction WEIV & WEIV-R & 0.8260 & -0.5636 & 0.6934 & 0.001 \\
\hline \multicolumn{6}{|c|}{ Plots not-containing $F$. excelsior: } \\
\hline Species richness & Rich & -0.6276 & 0.7785 & 0.8131 & 0.001 \\
\hline Shannon diversity index & Shan & -0.7372 & 0.6756 & 0.8253 & 0.001 \\
\hline Pielou evenness index & Even & -0.8622 & -0.5065 & 0.3712 & 0.001 \\
\hline Light WEIV & WEIV-L & 0.8501 & 0.5265 & 0.8822 & 0.001 \\
\hline Temperature WEIV & WEIV-T & -0.9937 & -0.1112 & 0.9577 & 0.001 \\
\hline Moisture WEIV & WEIV-F & -0.7042 & -0.7099 & 0.2214 & 0.001 \\
\hline Reaction WEIV & WEIV-R & -0.9744 & 0.2245 & 0.9323 & 0.001 \\
\hline \multicolumn{6}{|l|}{ Tree phorophyte: } \\
\hline Species richness & Rich & -0.6283 & -0.7779 & 0.7511 & 0.001 \\
\hline Shannon diversity index & Shan & -0.6215 & -0.7833 & 0.6826 & 0.001 \\
\hline Pielou evenness index & Even & 0.9381 & 0.3463 & 0.5069 & 0.019 \\
\hline Light WEIV & WEIV-L & -0.7060 & 0.7082 & 0.3919 & 0.072 \\
\hline Temperature WEIV & WEIV-T & 0.3073 & -0.9516 & 0.7217 & 0.001 \\
\hline Moisture WEIV & WEIV-F & -0.0530 & -0.9985 & 0.4520 & 0.042 \\
\hline Reaction WEIV & WEIV-R & 0.50031 & -0.8658 & 0.6872 & 0.004 \\
\hline
\end{tabular}

Determination coefficients $\mathrm{R}^{2}$ and P-values were estimated using permutation tests with 999 iterations. WEIV Wirth's ecological indicator value. Significant results are in bold

the bark of ash, 152 (about $90 \%$ of the total biota) were hosted by alternative tree phorophytes (tree species with the highest lichen biotas similarity to the biota of ash), with the highest number (101 species; about $60 \%$ of the total biota) of ash-associated lichens found for oak and hornbeam (Fig. 5). A slightly lower number of lichen species typically occurring on ash was found on lime, alder, and hazel (99, 97 and 71 epiphytes, respectively). Few epiphytic species were found on aspen, birch, and spruce.

At the community scale, the lichen biota of ash and alder differed in the presence and share of individual species. Out of 71 epiphytes analysed, 44 species showed significant differences in frequency between the two tree phorophytes considered (Fig. 6). We found 23 species (about $50 \%$ of the 44 discussed species) significantly associated to ash (e.g. Alyxoria varia, Inoderma byssaceum and Pertusaria coccodes), including 13 species which occurred on this tree exclusively (e.g. Acrocordia gemmata, Lepra albescens and Lobaria pulmonaria). Twenty-one species revealed significantly higher frequencies on alder than on ash (e.g.: Arthothelium ruanum, Fuscidea arboricola and Violella fucata). This group included four species, which grew on this phorophyte exclusively: Cladonia digitata, Arthonia spadicea, Felipes leucopellaeus and Chaenotheca ferruginea. 

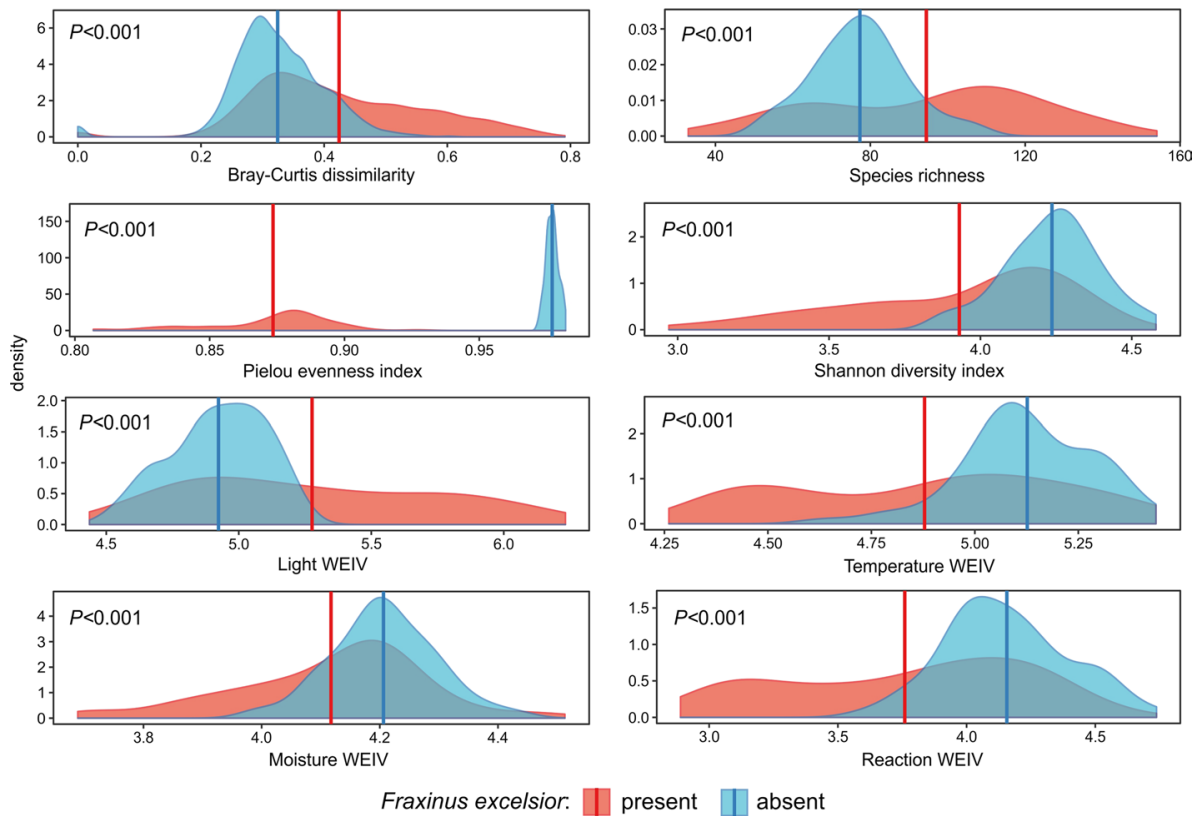

Fig. 3 Comparison of differences in Bray-Curtis dissimilarity index (calculated for each plot vs. each plot within each group of plots), species richness, Shannon diversity index, Pielou evenness index and mean values of Wirth's Ecological Indicator Values (WEIVs) between lichen biota on plots containing and not containing Fraxinus excelsior at the landscape scale using non-parametric Mann-Whitney $U$ test. Each ridge plot shows the density distribution of compositional traits compared. Thick vertical lines are means

\section{Discussion}

The European ash is characterized by a very high species richness of lichen epiphytes (Cieśliński et al. 1995). From all lichen species occurring in the area studied (about 320 species; see Łubek et al. 2018), about 50\% were recorded on the bark of this tree; thus, it is an important substrate providing appropriate conditions for lichens in maintaining the entire diversity of epiphytes. Our analyses revealed that even the complete extinction of ash will not pose a serious threat to the lichen biota associated with it. At the landscape scale, approximately $90 \%$ of epiphytic lichen biota connected with ash has the chance to survive on alternative tree hosts. Fifteen species occurring exclusively on ash (Supplementary Table 1) and belonging to $10 \%$ of species expected not to survive in the landscape scale, were mostly lichens of small thallus size, e.g. Bacidia biatorina, Candelariella efflorescens, Catillaria fungoides, Gyalecta flotowii, G. ulmi, Halecania viridescens, Psoroglaena abscondita. It could happen, that they were overlooked on other phorophyte species in investigated area. Among these lichens were both: species known as common in Poland (Fałtynowicz 2003) and in north-eastern Poland (Cieśliński 2003), e.g. Peltigera canina, $P$. polydactylon, Phaeophyscia orbicularis, as well as very rare and associated with wellpreserved forests (Cieśliński 2003; Kukwa et al. 2017), e.g. Arthothelium spectabile, Catillaria fungoides, Gyalecta flotowii, G. ulmi, Schismatomma pericleum. This group of species, with the exception of Bacidia biatorina, Candelariella efflorescens, Catillaria fungoides and Phaeophyscia orbicularis, is exclusively associated with the floodplain forest 


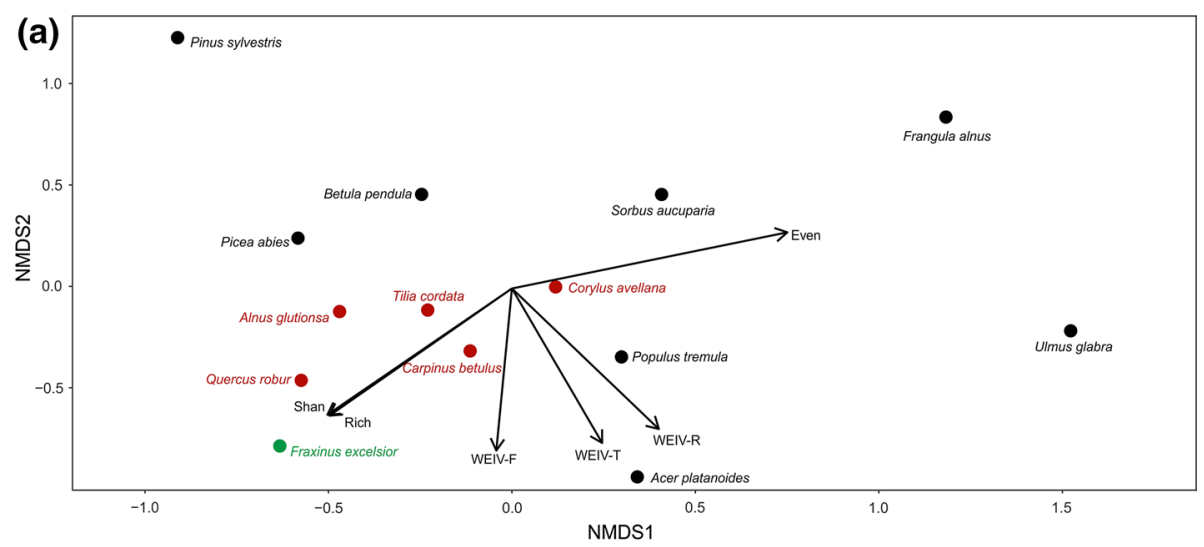

(b)

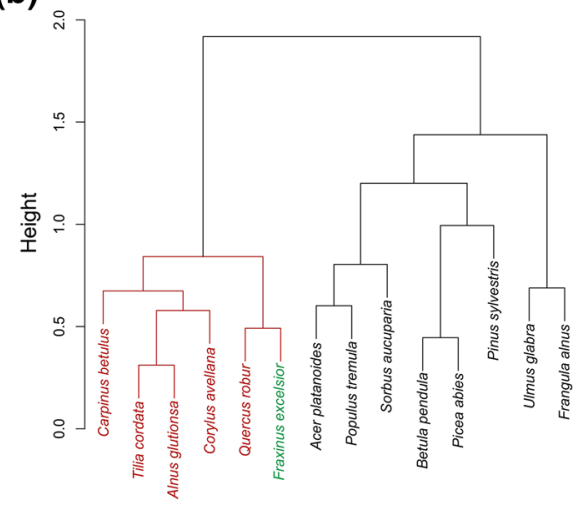

(c)

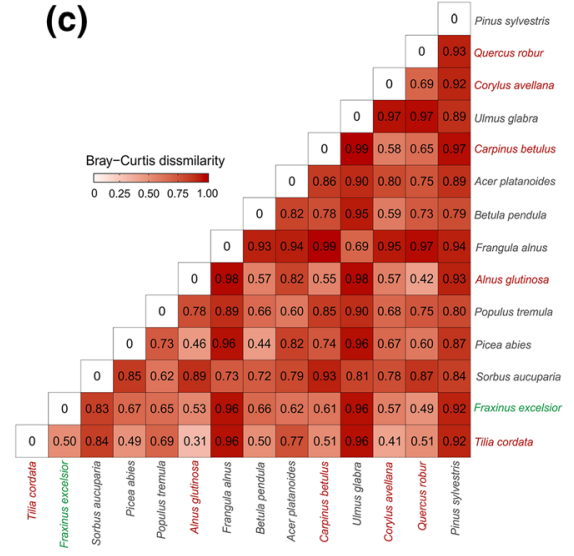

Fig. 4 Results of NMDS ordination performed for the species composition of epiphytic lichens on tree phorophytes at the landscape scale (a), hierarchal clustering analysis with a flexible-beta method showing the compositional dissimilarities among epiphytes occurring on tree phorophytes (b) and heat map showing the Bray-Curtis compositional dissimilarities of the same data (c). Five alternative tree hosts found to be the most similar to $F$. excelsior (marked in green color) in respect of epiphytes composition are marked in red. Arrows in (a) represent vectors significantly $(P<0.05)$ correlated with the analysis results: Rich-species richness, Shan-Shannon diversity index, WEIV-T_-temperature WEIV, WEIV-F-moisture WEIV, WEIV-R-reaction WEIV

community in our investigated area, thus their chances for survival are very low, no matter what spatial scale is applied.

Our analyses distinguished two distinct functional groups of ash-associated epiphytes. The first included species of higher light requirements (Fig. 2; compare Fig. 3), typical to a floodplain and to coniferous forests overexposed to light, which could be caused by natural windthrows and tree diebacks driven by insect outbreaks or fungal pathogens. In plots where ash did not occur, such species found suitable habitat conditions in coniferous communities, where they occupied mainly the branches of trees and deadwood in overexposed places (e.g. species from genera Cladonia, Hypogymnia, and Usnea). The second group included species of higher temperature requirements. These epiphytes (e.g. Thelotrema lepadinum, Ropalospora viridis, or some Pertusaria and Pyrenula species) were mostly linked to a mixed deciduous fertile oak-hornbeam forest. They were not associated strictly 


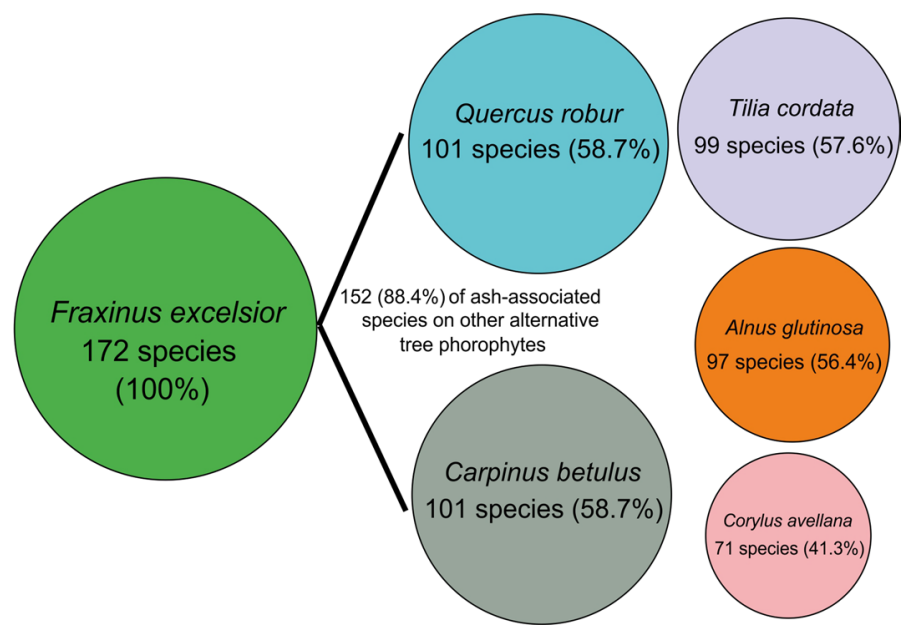

Fig. 5 Comparison of differences in share of ash-associated epiphytic lichen species inhabiting five most important alternative phorophyte species at the landscape scale

with ash (on which they occurred sporadically), but more often with the barks of hornbeam, lime, and hazel, which dominated in the mixed deciduous forest. These forests provide more stable temperature conditions and lower temperature fluctuations in comparison to more open floodplain forests occupying land depressions (Olszewski 1986). Due to that also epiphytes containing Trentepohlia algae as a photobiont (e.g. Arthonia, Pyrenula, and Opegrapha species), occur in the mixed deciduous forest as they have particular adaptation to environments with higher temperatures and higher humidity levels (Hametner et al. 2014). The species of the second group were also characterized by higher moisture requirements, related to stable humidity in the fertile oak-lime-hornbeam forest, as well as the lower acidity of occupied habitats (Figs. 2, 3). The presence of ash increased the species richness of the plots and their variability, which was reflected by the higher mean dissimilarity of their lichen biota, in comparison to plots without ash (Fig. 3). Epiphytes biota on plots with ash were also characterized by lower Pielou evenness and Shannon diversity, indicating the high importance of ash especially for very rare species.

Several tree species may play the role of alternative hosts for ash-associated lichens at the landscape level. The most important were oak and hornbeam. Each of these two tree species hosted close to $60 \%$ of the epiphytic lichens associated with ash (Fig. 5); however, these were not the same species groups and composition, and the share of lichen species on oak was more similar to that occurring on ash than to the species inhabiting hornbeam (Fig. 4b). Oaks and hornbeams were reported from the same site by Cieśliński et al. (1995) as the phorophytes hosting the highest number of lichen species. The importance of these trees for epiphytes is related to their high abundance in various forest communities: from shady humid oak-lime-hornbeam deciduous forest and moist oak-spruce mixed forest to the more overexposed pine-oak mixed forest. This wide habitat tolerance of oak and hornbeam, in combination with a wide spectrum of different microhabitat conditions, is suitable for hosting a high diversity of lichen epiphytes of different ecological requirements. The presence of several alternative tree species may solve the potential threat of a serious decline in lichen epiphytic biodiversity, but no single alternative tree can replace the ash as a phorophyte (Mitchell et al. 2014a). High similarity of ash and oak lichen biotas 


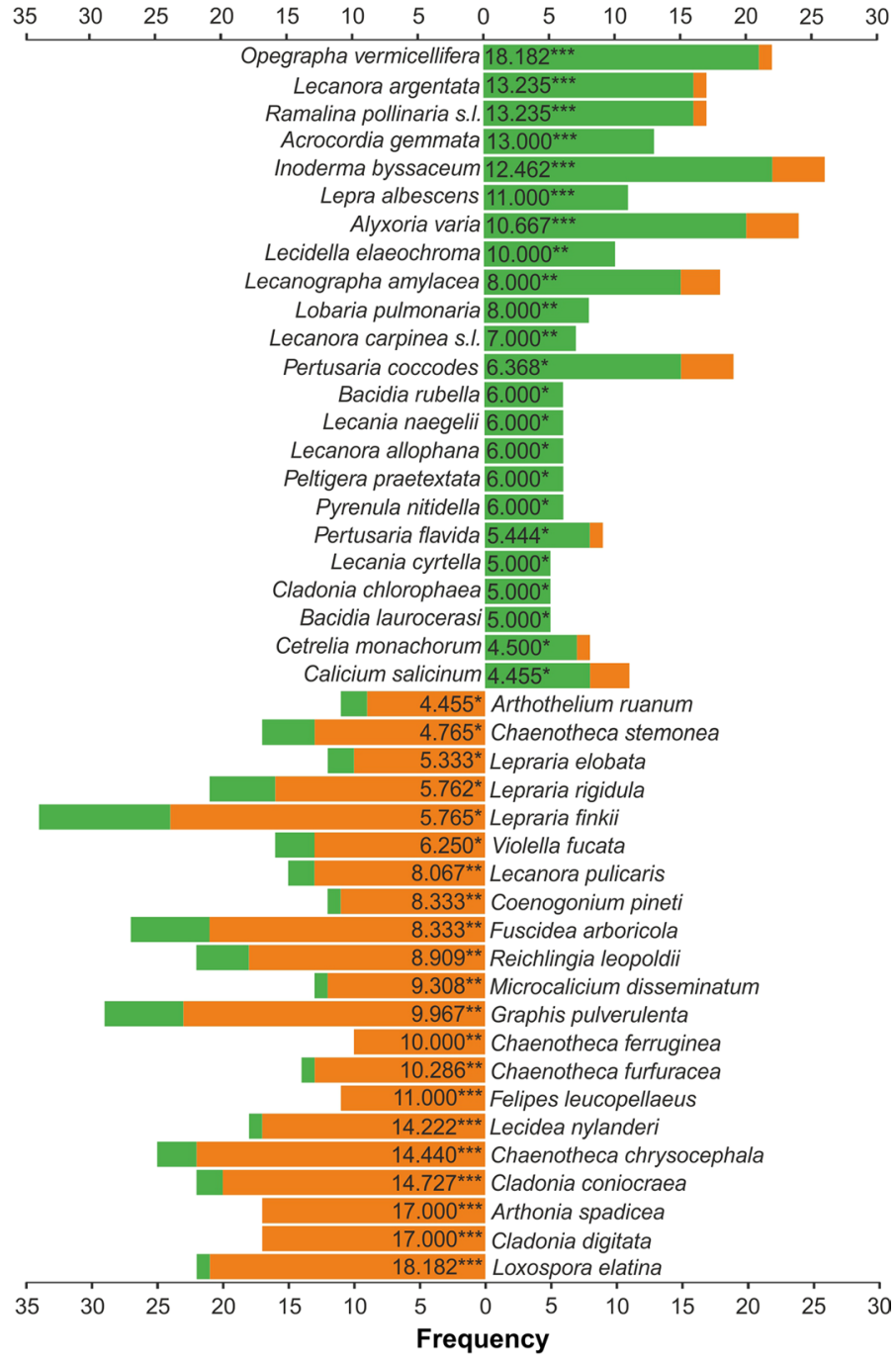

Tree phorophyte: Alnus glutinosa Fraxinus excelsior

Fig. 6 Significant $(P<0.05)$ differences in the frequency of lichen species at the community scale (floodplain forest Circaeo-Alnetum) between Fraxinus excelsior and Alnus glutinosa. Numbers in the bars are the $X^{2}$-statistics calculated from the Chi squared test. Significance of results: $* P<0.05, * * P<0.01$, $* * * P<0.001$

was reported from Great Britain by Ellis et al. (2013), which is congruent with our results (Fig. 4b). The next most similar phorophyte species in Great Britain were: beech, elm and sycamore, trees. At the landscape level of our study, aside from oak and hornbeam, lime, alder, and hazel also played an important role as substitute hosts for ash-associated lichens, often not occurring on the two formerly mentioned phorophyte species. Due to differences in species composition of lichens occupying different host tree species, nearly $90 \%$ of epiphyte species associated with ash are able to survive on them in the landscape scale 
context. Additionally, diseased or dead ash trees can still keep typical epiphytic lichens for some years, increasing the availability of their propagules and allowing them to spread. In such cases the persistence of lichen propagules in the environment increases the probability of their survival (Eaton et al. 2017; Ronnås et al. 2017; Wills et al., 2018). The extent and number of possible epiphytic lichen propagule sources within the landscape scale can prevent the species loss in the biota and facilitate their colonization on other microhabitats (Bouchard and Boudreault 2015). In this way, existing propagule sources of epiphytic lichen species maintain their dynamic and balance between mortality i.e. the extinction of local populations, and reproduction i.e. the recolonization of new microhabitats (Hanski 1998; Ruete et al. 2018), thus stabilizing entire metapopulations. This may be important for the restoration of ash-associated lichen biota after the regeneration of ash population, which recently almost entirely retreated from the forests. The reconstruction of the earlier full epiphytic biota on new generations of ash may be possible due to their refuges: i.e. alternative hosts and alternative microhabitats like dead wood. Thus, the dieback of ash at the landscape scale, where ash occurs as an admixture tree in various communities, is not problematic for the survival of most epiphytic lichens, if the forest is large enough to maintain its ecological continuity and natural regeneration processes (Angelstam and Kuuluvainen 2004; Shorohova et al. 2009). The biota of epiphytes needs not only a specific tree but also other species of phorophytes, specific microhabitats, and suitable space to maintain its continuity.

At the community scale, the dieback of ash could pose a higher threat to the ash-associated biota of epiphytes. Only about $50 \%$ of the species hosted by ash were recorded on the bark of alder (Fig. 6), the second main tree building floodplain alder-ash forests. Remaining lichen species may not find, in the limits of this community, trees with suitable microhabitats. Moreover, ash dieback at the community level could be a threat especially to very rare lichens, e.g. Opegrapha vermicellifera, Inoderma byssaceum and Alyxoria varia, realizing narrow niches and occurring within small populations (Jönsson and Thor 2012; Lõhmus and Runnel 2014). Similarly, the lack of alternative host trees for other species, e.g. Lepra albescens, Lobaria pulmonaria, and Peltigera praetextata, may reduce the chances for their survival at the community scale of floodplain forest. In our study, the bark of lying dead ash was an important substrate for some epiphytes that had previously grown on living ashes. In such a case, if the ash population will not recover, with progressive wood decomposition and the change in microhabitat conditions, they will not have any further prospects for survival (the "extinction debt" sensu Tilman et al. 1994). At the community scale, a specific ecological trap is created (Schlaepfer et al. 2002; Hale et al. 2015; Hale and Swearer 2016) due to the lower diversity of tree phorophytes, especially for lichens that exclusively or more often choose ash as a substrate for their occurrence. Thus, when there is a lack of ash phorophytes offering high-quality habitat conditions, ash-dependent lichens may colonize alders, which may be treated here as lower-quality phorophytes due to their different bark structure in comparison with ash (Barkman 1958). This may lead to lowered growth of lichen thalli, as has been recorded in Estonian forests (Lõhmus and Runnel 2014), their rapid die-off, or a complete lack of growth. Floodplain communities composed of alder can be a sink habitat for some epiphyte species, due to the limited possibilities of lichen migration to other alternative host trees.

Some authors (e.g. Ellison et al. 2005; Lõhmus and Runnel 2014; Brzeziecki et al. 2016) have suggested that changes in forest structure, caused by the massive dieback of one foundation tree species, like ash, result in irreversible changes in the species diversity of some groups of organisms, e.g. insects, bryophytes, lichens, and fungi, whose occurrence depends on the presence of this tree. Such a scenario is possible on a fine scale of the 
fragmented or isolated community patches composed of several species of trees, such as swamp or floodplain forests in a transformed landscape. However, such a scenario will not take place in extensive forest areas characterized by high naturalness and a large diversity of microhabitats, e.g.: trees of diverse species in age (from youngest to oldest) and deadwood in different stages of decomposition. These forests have specific dynamics, where natural disturbances like fungus or insect caused dieback of trees, are part of it. Even more, the dying of trees that dominate the canopy creates gaps, delivers dead wood, and allows forest regeneration, resulting in the development of communities of organisms dependent on this disturbance-caused habitat conditions (Kimmins 2003; Gilliam 2007; Stokland et al. 2012; Götmark 2013). Such significant changes of forest structure caused by hostspecific pathogens that target a dominant forest tree species, have also been reported for several other species: oak, elm, pine, spruce, and alder (Fajvan and Wood 1996; Peterken and Mountford 1998; Kurz et al. 2008; Hicke et al. 2012; Bjelke et al. 2016). The decline in their populations causes an increase in the abundance of other tree species, which at least partly replace them as phorophytes. For instance, the loss of ash in British woodlands has increased the sycamore population (Needham et al. 2016). The same authors concluded that the long-term population dynamics of European ash are shaped by short-term pathogen-induced mortality, and even after reduction of the ash population by $75 \%$ it recovers to near pre-disturbance level-if the proportion of resistant individuals is high enough or a significant share of the population escape infection (Needham et al. 2016; Coker et al. 2019). In Białowieża National Park, a fungal pathogen caused the reduction of the ash population by over $90 \%$ during less than two decades (Cholewińska et al. 2018). The same authors have documented also the natural regeneration of ash; however, they observed that even young individuals were affected by the pathogen as well, which may pose a serious threat to ash-associated organisms. In other sites where ash regeneration is observed, e.g.: in Latvia (Pušpure et al. 2017) and South-Western Germany (Enderle et al. 2018), young trees seemed to be resistant to Hymenoscyphus fraxineus infection. If the ash in Białowieża Forest regenerate, there is a chance that the new generation will be resistant as well, and the epiphytes growing on this tree will have a chance to restore due to source propagules occurring on alternative tree phorophytes: mainly the oak and hornbeam-hot spot trees for epiphytic lichens, as well as other alternative host trees like lime and, in the longer perspective, by alder and hazel.

The extinction of ash at the scale of a floodplain streamside alder-ash forest community may result in the reduction of species diversity of epiphytic lichen associated with this phorophyte. Only about $50 \%$ of species were able to survive on the bark of alder-the second dominant tree species of the community. Forest communities composed of a few species of trees, such as floodplain forests, despite century-long strict protection and specific occurrence within an extensive forest complex, are less resistant to disturbances and thus are exposed to the risk of loss of species diversity.

\section{Conclusions}

The preservation of extensive forest areas, with high species diversity of trees and a high diversity of communities increases the chances for preserving species diversity of epiphytic lichens. The greater the phorophyte diversity, the greater the microhabitat diversity for lichens, and the greater the chance of survival of all species, especially those sensitive and associated with specific microhabitats. 
Our results highlight the importance of a spatial scale in biological conservation. The protection of large, well preserved forest areas with a rich diversity of phorophyte trees as source habitats for epiphytic lichens will allow the continuity of lichen epiphytes metapopulations to remain dynamic and preserve their species diversity. However, the results obtained in our study should be referred with a caution in relation to other forest areas of different geographical location due to their different and specific regional climatic conditions significantly affecting species diversity of lichens.

Author contributions A.E. and M.K. elaborated the main objectives of the study and collected the data; P.C. and A.Ł. analysed data; A.Ł. prepared the manuscript, with contributions of all other authors.

Funding The research leading to these results has received funding from the Polish-Norwegian Research Programme operated by the National Centre for Research and Development under the Norwegian Financial Mechanism 2009-2014 in the frame of Project Contract No. Pol-Nor/196829/87/2013.

\section{Compliance with ethical standards}

Conflict of interest The authors declare no competing interests.

Open Access This article is distributed under the terms of the Creative Commons Attribution 4.0 International License (http://creativecommons.org/licenses/by/4.0/), which permits unrestricted use, distribution, and reproduction in any medium, provided you give appropriate credit to the original author(s) and the source, provide a link to the Creative Commons license, and indicate if changes were made.

\section{References}

Allen CD, Macalady AK, Chenchouni H, Bachelet D, Mcdowell N, Vennetier M et al (2010) A global overview of drought and heat-induced tree mortality reveals emerging climate change risks for forests. For Ecol Manag 259(4):660-684

Angelstam P, Kuuluvainen T (2004) Boreal forest disturbance regimes, successional dynamics and landscape structures-a European perspective. Ecol Bull 51:117-136

Bakys R, Vasaitis R, Barklund P, Thomsen IM, Stenlid J (2009a) Occurrence and pathogenicity of fungi in necrotic and nonsymptomatic shoots of declining common ash (Fraxinus excelsior) in Sweden. Eur J Forest Res 128:51-60

Bakys R, Vasaitis R, Barklund P, Ihrmark K, Stenlid J (2009b) Investigations concerning the role of Chalara fraxinea in declining Fraxinus excelsior. Plant Pathol 58:284-292

Baral H-O, Queloz V, Hosoya T (2014) Hymenoscyphus fraxineus, the correct scientific name for the fungus causing ash dieback on Europe. IMA Fungus 5:79-80

Barkman JJ (1958) Phytosociology and ecology of cryptogamic epiphytes. Van Gorcum, Assen

Beck P, Caudullo G, Tinner W, de Rigo D (2016) Fraxinus excelsior in Europe: distribution, habitat, usage and threats. In: San-Miguel-Ayanz J, de Rigo D, Caudullo G, Durrant TH, Mauri A (eds) European atlas of forest tree species. EU Publications, Luxembourg, p e0181c0+

Bjelke U, Boberg J, Oliva JA, Tattersdill K, Mckie BG (2016) Dieback of riparian alder caused by the Phytophthora alni complex: projected consequences for stream ecosystems. Freshw Biol 61:565-579. https://doi.org/10.1111/fwb.12729

Boluda CG, Rico VJ, Divakar PK, Nadyeina O, Myllys L, McMullin RT et al (2019) Evaluating methodologies for species delimitation: the mismatch between phenotypes and genotypes in lichenized fungi (Bryoria sect. Implexae, Parmeliaceae). Persoonia 42:75-100. https://doi.org/10.3767/perso onia.2019.42.04

Bouchard M, Boudreault C (2015) Is metapopulation size important for the conservation of understory plants and epiphytic lichens? Biol Conserv 195:187-195. https://doi.org/10.1016/j.biocon.2015.12.029 
Brzeziecki B, Pommerening A, Miścicki S, Drozdowski S, Żybura H (2016) A common lack of demographic equilibrium among tree species in Białowieża National Park (NE Poland): evidence from longterm plots. J Veg Sci 27(3):460-469. https://doi.org/10.1111/jvs.12369

Cholewińska O, Keczyński A, Smerczyński I, Jaroszewicz B (2018) European ash (Fraxinus excelsior L.) dieback in a core area of Białowieża National Park. Parki narodowe i Rezerwaty Przyrody 37(2):3-18

Cieśliński S (2003) Distribution atlas of lichens (Lichenes) in North-Eastern Poland. Phytocoenosis 15((N.S.) Supp. Cartog. Geobot.):1-430

Cieśliński S, Czyżewska K (1997) Cryptogamous plants in the forest communities of Białowieża National Park. Ecological Atlas. Lichens (Project CRYPTO 4). Phytocoenosis 7(9 (N.S), Supp. Cartog. Geobot.):123-163

Cieśliński S, Czyżewska K, Glanc K (1995) Lichenes. In: Faliński JB, Mułenko W (eds) Cryptogamous plants in the forest communities of Białowieża National Park. General problems and taxonomic groups analysis (Project CRYPTO 2), vol 7. Phytocoenosis (N.S.), Arch. Geobot. Wydawn, Warsaw, pp 75-86

Coker TL, Rozsypálek J, Edwards A, Harwood TP, Butfoy L, Buggs RJA (2019) Estimating mortality rates of European ash (Fraxinus excelsior) under the ash dieback (Hymenoscyphus fraxineus) epidemic. Plants People Planet 1:48-58. https://doi.org/10.1002/ppp3.11

Czarnota P, Guzow-Krzemińska B (2018) Bacidina mendax sp nov, a new widespread species in Central Europe, together with a new combination within the genus Bacidina. Lichenologist 50(1):43-57. https://doi.org/10.1017/S0024282917000627

Eaton S, Zúñiga C, Czyzewski J, Ellis C, Genney DR, Haydon D et al (2017) A method for the direct detection of airborne dispersal in lichens. Mol Ecol Resour. https://doi. org/10.1111/1755-0998.12731

Ellis CJ, Coppins BJ, Eaton S, Simkin J (2013) Implications of ash dieback for associated epiphytes. Conserv Biol 27(5):899-901

Ellison AM, Bank MS, Clinton BD, Colburn EA, Elliott K, Ford CR et al (2005) Loss of foundation species: consequences for the structure and dynamics of forested ecosystems. Front Ecol Environ 3:479-486

Enderle R, Nakou A, Thomas K, Metzler B (2015) Susceptibility of autochthonous German Fraxinus excelsior clones to Hymenoscyphus pseudoalbidus is genetically determined. Ann For Sci 72(2):183-193. https://doi.org/10.1007/s13595-014-0413-1

Enderle R, Metzler B, Riemer U, Kändler G (2018) Ash dieback on sample points of the national forest inventory in South-Western Germany. Forests 9(1):25. https://doi.org/10.3390/f9010025

Ertz D, Sanderson N, Łubek A, Kukwa M (2018) Two new species of Arthoniaceae from old-growth European forests: Arthonia thoriana and Inoderma sorediatum, and a new genus for Schismatomma niveum. Lichenologist 50(2):161-172

Eschtruth AK, Cleavitt NL, Battles JJ, Evans RA, Fahey TJ (2006) Vegetation dynamics in declining eastern hemlock stands: 9 years of forest response to hemlock woolly adelgid infestation. Can J For Res 36:1435-1450. https://doi.org/10.1139/x06-050

Fajvan MA, Wood JM (1996) Stand structure and development after gypsy moth defoliation in the Appalachian Plateau. For Ecol Manag 89(1-3):79-88. https://doi.org/10.1016/S0378-1127(96)03865-0

Faliński JB, Mułenko W (1997) Cryptogamous plants in the forest communities of Białowieża National Park. Ecological atlas (Project CRYPTO 4). Phytocenosis 7(9 (N.S.) Suppl Cart Geobot):1-512

Fałtynowicz W (2003) The lichens, lichenicolous and allied fungi of Poland. An annotated checklist. W. Szafer Institute of Botany, Polish Academy of Sciences, Kraków, pp 1-435

Fałtynowicz W, Kossowska M (2016) The lichens of Poland. A fourth checklist. Acta Bot Sil Monogr $8: 3-122$

Ford CR, Elliott KJ, Clinton BD, Kloeppel BD, Vose JM (2012) Forest dynamics following eastern hemlock mortality in the southern Appalachians. Oikos 121:523-536

Gilliam F (2007) The ecological significance of the herbaceous layer in temperate forest ecosystems. Bioscience 57:845-858

Götmark F (2013) Habitat management alternatives for conservation forests in the temperate zone: review, synthesis, and implications. For Ecol Manag 306:292-307. https://doi.org/10.1016/j.forec o.2013.06.014

Gross A, Holdenrieder O, Pautasso M, Queloz V, Sieber TN (2014a) Hymenoscyphus pseudoalbidus, the causal agent of European ash dieback. Mol Plant Pathol 15(1):5-21

Gross A, Hosoya T, Queloz V (2014b) Population structure of the invasive forest pathogen Hymenoscyphus pseudoalbidus. Mol Ecol 23(12):2943-2960. https://doi.org/10.1111/mec.12792

Hale R, Swearer SE (2016) Ecological traps: current evidence and future directions. Proc R Soc B 283:20152647. https://doi.org/10.1098/rspb.2015.2647 
Hale R, Treml EA, Swearer SE (2015) Evaluating the metapopulation consequences of ecological traps. Proc R Soc B 282:20142930. https://doi.org/10.1098/rspb.2014.2930

Hametner Ch, Stocker-Wörgötter E, Grube M (2014) New insights into diversity and selectivity of Trentepohlialean lichen photobionts from the extratropics. Symbiosis 63:31-40. https://doi. org/10.1007/s13199-014-0285-z

Hanski I (1998) Metapopulation dynamics. Nature 396(6706):41-49. https://doi.org/10.1038/23876

Hicke JA, Allen CD, Desai AR, Dietze MC, Hall RJ, Hogg EH et al (2012) Effects of biotic disturbances on forest carbon cycling in the United States and Canada. Glob Change Biol 18(1):7-34

Jönsson MT, Thor G (2012) Estimating coextinction risks from epidemic tree death: affiliate lichen communities among diseased host tree populations of Fraxinus excelsior. PLoS ONE 7(9):e45701. https://doi. org/10.1371/journal.pone.0045701

Keczyński A (ed) (2017) The Forests of the Strict Reserve of Białowieża National Park. Białowieski Park Narodowy, Białowieża, p 304

Kimmins JP (2003) Old-growth forest: An ancient and stable sylvan equilibrium, or a relatively transitory ecosystem condition that offers people a visual and emotional feast? Answer-it depends. For Chron 79(3):429-440. https://doi.org/10.5558/tfc79429-3

Kowalski T, Holdenrieder O (2009a) Pathogenicity of Chalara fraxinea. For Pathol 39:1-7

Kowalski T, Holdenrieder O (2009b) The teleomorph of Chalara fraxinea, the causal agent of ash dieback. For Pathol 39:304-308

Kukwa M, Czarnota P, Łubek A (2017) Three lichen species in Buellia, Catillaria, and Cheiromycina, new to Poland. Mycotaxon 132:177-182. https://doi.org/10.5248/132.177

Kurz WA, Dymond CC, Stinson G, Rampley GJ, Neilson ET, Carroll AT et al (2008) Mountain pine beetle and forest carbon feedback to climate change. Nature 452:987-990

Latałowa M, Zimny M, Pędziszewska A, Kupryjanowicz M (2016) Postglacial history of Białowieża Forest-vegetation, climate and human activity. Parki narodowe i Rezerwaty Przyrody 35(1):3-49

Lõhmus A, Runnel K (2014) Ash dieback can rapidly eradicate isolated epiphyte populations in production forests: a case study. Biol Conserv 169:185-188. https://doi.org/10.1016/j.biocon.2013.11.031

Łubek A, Kukwa M, Jaroszewicz B, Czortek P (2018) Changes in the epiphytic lichen biota of Białowieża Primeval Forest arenot explained by climate warming. Sci Total Environ 643:468-478. https://doi. org/10.1016/j.scitotenv.2018.06.222

Lücking R, Moncada B, Hawksworth DL (2019) Gone with the wind: sequencing its type species supports inclusion of Cryptolechia in Gyalecta (Ostropales: Gyalectaceae). Lichenologist 51(4):287-299. https ://doi.org/10.1017/S0024282919000240

Maechler M (2019) Package 'cluster': "Finding groups in Data": Cluster Analysis Extended Rousseeuw et al."

Malzahn E (2004) Change direction of the air pollution level and climatic factors in the Białowieża Primeval Forest. Leśne Prace Badawcze 1:55-85

Malzahn E, Kwiatkowski W, Pierzgalski E (2009) Przyroda nieożywiona. Klimat. In: Okołów C, Karaś M, Bołbot A (eds) Białowieski Park Narodowy. Wyd. Białowieski Park Narodowy, Białowieża, pp 18-33

Matisone I, Matisons R, Laiviņš M, Gaitnieks T (2018) Statistics of ash dieback in Latvia. Silva Fennica 52(1):6. https://doi.org/10.14214/sf.9901

Mitchell RJ, Bailey S, Beaton JK, Bellamy PE, Brooker RW, Broome A et al (2014a) The potential ecological impact of ash dieback in the UK. JNCC Report No. 483

Mitchell RJ, Beaton JK, Bellamy PE, Broome A, Chetcuti J, Eaton S et al (2014b) Ash dieback in the UK: a review of the ecological and conservation implications and potential management options. Biol Conserv 175:95-109

Mitchell RJ, Hewison RL, Hester AJ, Broome A, Kirby KJ (2016) Potential impacts of the loss of Fraxinus excelsior (Oleaceae) due to ash dieback on woodland vegetation in Great Britain. New J Bot 6(1):2-15. https://doi.org/10.1080/20423489.2016.1171454

Monitoring Lasów w Polsce. Raport (2000) Stan zdrowotny lasów Polski w roku 2000. Instytut Badawczy Leśnictwa. Zakład Urządzania i Monitoringu Lasu. http://www.gios.gov.pl/monlas/raporty.html [Health condition of Polish forests in 2000. Forest Monitoring in Poland. Report]

Monitoring Lasów w Polsce. Raport (2003) Stan zdrowotny lasów Polski w roku 2003. Instytut Badawczy Leśnictwa. Zakład Urządzania i Monitoringu Lasu. http://www.gios.gov.pl/monlas/raporty.html [Health condition of Polish forests in 2003. Forest Monitoring in Poland. Report]

Monitoring Lasów w Polsce. Raport (2013) Stan zdrowotny lasów Polski w roku 2013 - synteza. Instytut Badawczy Leśnictwa. Zakład Urządzania i Monitoringu Lasu. http://www.gios.gov.pl/monlas/rapor ty/raport_2013/01.html [Health condition of Polish forests in 2013 - synthesis. Forest Monitoring in Poland. Report] 
Monitoring Lasów w Polsce. Raport (2015) Stan zdrowotny lasów Polski w roku 2015 - synteza. Instytut Badawczy Leśnictwa. Zakład Urządzania i Monitoringu Lasu. http://www.gios.gov.pl/monlas/rapor ty/raport_2015/01.html [Health condition of Polish forests in 2015 - synthesis. Forest Monitoring in Poland. Report]

Nakagawa S, Cuthill IC (2007) Effect size, confidence interval and statistical significance: a practical guide for biologists. Biol Rev 82:591-605. https://doi.org/10.1111/j.1469-185X.2007.00027.x

Needham J, Merow C, Butt N, Malhi Y, Marthews TR, Morecroft M, McMahon SM (2016) Forest community response to invasive pathogens: the case of ash dieback in a British woodland. J Ecol 104:315330. https://doi.org/10.1111/1365-2745.12545

Oksanen J, Blanchet FG, Kindt R, Legendre P, Minchin PR, O’Hara RB et al (2018) Package ‘vegan’Community Ecology Package

Olszewski JL (1986) Rola ekosystemów leśnych w modyfikacji klimatu lokalnego Puszczy Białowieskiej. Habilitation work. Ossolineum, Wrocław, pp 1-222

Pautasso M, Aas G, Queloz V, Holdenrieder O (2013) European ash (Fraxinus excelsior) dieback-A conservation biology challenge. Biol Cons 158:3739

Peterken GF, Mountford EP (1998) Long-term change in an unmanaged population of wych elm subjected to Dutch elm disease. J Ecol 86:205-218

Pipp AK, Henderson C, Callaway RM (2001) Effects of forest age and forest structure on epiphytic lichen biomass and diversity in a douglas-fir forest. Northwest Sci 75(1):12-24

Preikša Ž, Brazaitis G, Marozas V, Jaroszewicz B (2015) Dead wood quality influences diversity of rare cryptogams in temperate broadleaved forests of Eastern Europe. iForest Biogeosci For. https://doi. org/10.3832/ifor1483-008

Przybył K (2002) Fungi associated with necrotic apical parts of Fraxinus excelsior shoots. For Pathol 32:387-394. https://doi.org/10.1046/j.1439-0329.2002.00301.x

Pušpure I, Matisons R, Laiviņš M, Gaitnieks T, Jansons J (2017) Natural regeneration of common ash in young stands in Latvia. Baltic Forestry 23:209-217

R Core Team (2019) R: a language and environment for statistical computing. R Foundation for Statistical Computing, Vienna

Ronnås C, Werth S, Ovaskainen O, Vårkonyi G, Scheidegger C, Snäll T (2017) Discovery of long-distance gamete dispersal in a lichen-forming ascomycete. New Phytol 216(1):216-226. https://doi. org/10.1111/nph.14714

Ruete A, Jönsson MT, Snäll T (2018) Conservation benefits of international Aichi protection and restoration targets for future epiphyte metapopulations. J Appl Ecol 55(1):118-128. https://doi. org/10.1111/1365-2664.12964

Sabatini FM, Burrascano S, Keeton WS, Levers C, Lindner M, Pötzschner F et al (2018) Where are Europe's last primary forests? Diver Distrib 24:1426-1439. https://doi.org/10.1111/ddi.12778

Schlaepfer MA, Runge MC, Sherman PW (2002) Ecological and evolutionary traps. Trends Ecol Evol 17(10):474-480. https://doi.org/10.1016/S0169-5347(02)02580-6

Sérusiaux E, Brand AM, Motiejunaite J, Orange A, Coppins BJ (2010) Lecidea doliiformis belongs to Micarea, Catillaria alba to Biatora, and Biatora ligni-mollis occurs in Western Europe. Bryologist 113(2):333-344. https://doi.org/10.1639/0007-2745-113.2.333

Shorohova E, Kuuluvainen T, Kangur A, Jogiste K (2009) Natural stand structures, disturbance regimes and successional dynamics in the Eurasian boreal forests: a review with special reference to Russian studies. Ann For Sci 66:201-220

Skovsgaard JP, Thomsen IM, Skovgaard IM, Martinussen T (2010) Associations among symptoms of dieback in even-aged stands of ash (Fraxinus excelsior L.). For Pathol 40:7-18. https://doi.org/10.111 1/j.1439-0329.2009.00599.x

Steel EA, Kennedy MC, Cunningham PG, Stanovick JS (2013) Applied statistics in ecology: common pitfalls and simple solutions. Ecosphere 4(9):art115. https://doi.org/10.1890/ES13-00160.1

Stokland JN, Siitonen J, Jonsson BG (2012) Biodiversity in Dead Wood. Cambridge University Press, Cambridge

Tilman E, May RM, Lehman CL, Nowak M (1994) Habitat destruction and the extinction debt. Nature 371:65-66

van Herk CM (2009) Climate change and ammonia from cars as notable recent factors influencing epiphytic lichens in Zeeland, Netherlands. Bibliotheca Lichenologica 99:205-224

Wills A, Cranfield R, Ward B, Tunsell V (2018) Cryptogam recolonization after wildfire: leaders and laggards in assemblages? Fire Ecol 14(1):65-84

Wirth V (2010) Ökologische Zeigerwerte von Flechten. Herzogia 23(2):229-248 
Publisher's Note Springer Nature remains neutral with regard to jurisdictional claims in published maps and institutional affiliations.

\section{Affiliations}

\section{Anna Łubek ${ }^{1}$ (D) Martin Kukwa² $\cdot$ Patryk Czortek ${ }^{3} \cdot$ Bogdan Jaroszewicz $^{3}$}

1 Institute of Biology, The Jan Kochanowski University in Kielce, Świętokrzyska 15A, 25-406 Kielce, Poland

2 Faculty of Biology, Department of Plant Taxonomy and Nature Protection, University of Gdańsk, Wita Stwosza 59, 80-308 Gdańsk, Poland

3 Faculty of Biology, University of Warsaw, Białowieża Geobotanical Station, Sportowa 19, 17-230 Białowieża, Poland 